\title{
STUDENTS' MOVEMENT AND POLITICAL PARTICIPATION: RESEARCH ON THE ASSOCIATION OF ISLAMIC STUDENT IN INDONESIA
}

\author{
Ismail Suardi Wekke \\ Ford Foundation International Fellowship Program \\ Faculty of Education, Universiti Kebangsaan Malaysia \\ No. 8-1A, J1. Hentian 5, Pusat Hentian Kajang 43000, Selangor, D.E. \\ Cellphone: +60-16-240-2389 Faks. +60-3-8736-7334 \\ Email: iswekke@antarbangsa.net \\ Sidratahta Mukhtar \\ Graduate School of Political Science \\ Faculty of Social and Political Science, Universitas Indonesia \\ Jl. Matraman Kav. 3-5-7 Suite 77, Jakarta Timur 13150, Indonesia \\ Phone: +62-21-851-8193 Faks. +62-21-8591-1590 \\ Email: lintas@antarbangsa.net
}

\section{PRESENTED IN}

The 3rd International Malaysia-Thailand Conference on Southeast Asian Studies

Salaya Pavilion Hotel, Bangkok, Thailad

Collaboration Between

Faculty of Social Sciences and Humanities, Universiti Kebangsaan Malaysia (UKM) and Social Science Division of Mahidol University

November 29 to December 1, 2007

\begin{abstract}
Indonesian student movement engages in political participation since Budi Oetomo declared Kebangkitan Nasional (national awakening) in 1908 to nowadays called reformation era. It proves that student activities in Indonesia a part of political process as "an extra parlement". One of the student movements is Himpunan Mahasiswa Islam (HMI - The Association of Islamic University Students), a student movement shaped by Islamic value system. This paper tries to examine the practices of HMI in order to realize Islam as a way of life and a universal value relating to politics performance. This study was conducted in Himpunan Mahasiswa Islam, data were collected purposively in Jakarta. Interview with Pengurus Besar (National Board), non-participant observation and documentation study were arranged. The research shows that HMI (sixty years involvement) since 1947 is an instrumental part on Indonesian educational and political activities progress in enhancing and developing the potency of youth generation. Furthermore, this paper will give an example of activities that were designed not only to develop the students' skills of knowledge but also to raise awareness of political activities and how this relates to Islamic belief. Through involvement in wide range activity is one way to increase awareness among students of the possibilities to learn about and practice management and leadership skills. After graduation from the universities many students chair political party activities and appoint in various positions within government institutions. As a result, those activities allow them participate in Indonesia development and contribute to national progress that direct by Islamic belief, value and culture.
\end{abstract}




\section{INTRODUCTION}

Himpunan Mahasiswa Islam (HMI, The Association of Islamic University Students) is one of the oldest and the biggest university students' organization in Indonesia. It was founded on the 5 February 1947 in Yogyakarta, two years after the Independence Day of Republic Indonesia. HMI always play strategic roles in every challenge that must be faced by ummah (Islamic society) and this nation. Whereas, Victor Tanja (1982) proposed that, "history of HMI closely tied with Indonesian modern history perfectly.” This condition caused that HMI get many notice from intellectual communities both inside and outside of this country. There are many works and studies dealing with HMI, such as, Agussalim Sitompul written the book entitled Sejarah HMI dan Pemikiran Keislaman HMI (History and Islamic Thought of HMI) (1975, 1995, 2002), Muhammad Kemal Hassan written dealing with Peran HMI Dalam Modernisasi Indonesia (Role of HMI in Indonesian Modernization) (1987), Victor Tanja written about Kedudukan HMI Sebagai Kekuatan Pembaharu (The Position of HMI as New Strength) (1983), Greg Barton written dealing with idea of Islam Liberal di Indonesia (Islamic Liberal in Indonesia) (1999). Prior to Hasanuddin M. Saleh worked on research dealing with HMI dan Rekayasa Asas Tunggal Pancasila (HMI and Changes to The Only Fundament Organization of Pancasila) (1996), and Masykur Hakim conducted a research as his dissertation dealing with HMI Dalam Pergolakan Reformasi Dan Strategi HMI (HMI in The Turbulence of Reformation and The Strategy of HMI) (2001).

This research eager to testify once again how far the role of HMI in creating opportunities for Islamic student to participate in political activities. Victor Tanja research findings stated that HMI has played very important role in the Republic of Indonesia's journey which is full of challenges from time to times. The phenomena of HMI moment is really interesting, especially dealing with its success to create national political cadres, so they always ready for filling the recruitment of national leadership since Old Order Period, New Order Period and even in this Reformation Period.

\section{LITERATURE REVIEW}

There are several books which are reviewed in this writing, the book was written by Victor Tanja (1982), dissertation was written by Syaifullah S.A. dealing with Nationalism of HMI (1994), Hasanuddin M. Saleh, one of founder HMI MPO, written about HMI and Changes to

The Only Fundament Organization of Pancasila (1996), and dissertation which discussed about Reformation Movement and Strategy of HMI written by Masykur Hakim (2001). 
Hasanuddin stated that HMI face the deep and long internal challenges or internal conflicts as impact of New Order Period's pressure to accept The Only Fundament Organization of Pancasila systematically. Although at Congress XV, in Medan 1983, HMI still accept The Only Fundament Organization of Pancasila explicitly. However, through many alumni of HMI in the circle of power has intervened to accept the Only Fundament Organization of Pancasila.

Meanwhile, Hakim stated that HMI still be determined to involve with New Order Period and see the needs to take a part in political activities by coming to economic and political institutions. KAHMI (Korps Alumni HMI / Corps of Alumni HMI) has served many government institutions. Several of them chair on second technocrat strata, such as, Cokroamijoyo, Deliar Noer, Marli Halim, Madjib Ibrahim, Zainul Asni, Omar Tusin, Bustanul Arifin and Hariry Hady. In fact, some of them sit on ministry position, such as, Abdul Gafur, Akbar Tandjung, Mar'ie Muhammad, Minteredjo, etc. In its history, Indonesian Islamic ummah have used political party and mass organization as political media. But HMI never made affiliated with political party formally, because accordance with its principal which is independence principal.

In studying result of Victor Tanja's research, Hasanuddin, Masykur Hakim, and the others, the writer uses some of theory dealing with political education and political participation. The concept that developed by Samuel P. Huntington and Kartini Kartono are still relevance become as analysis tool to measure the HMI tendency's on forming cadre and political participation in the circle of power in long time. In fact, the role of HMI cause problem. Anas Urbaningrum, for example, can not deny the tendency of HMI to political orientation.

\begin{abstract}
"Although the struggle of HMI is the struggle of truth, but as organization which has developed, including it has contact with the dynamic of nation political, then every attitude and behavior of HMI will still have the political values and resonance. In the beginning, the posture of HMI as moral force, like or dislike also counted as political force." (See Formulate The Political Position of HMI, Media Indonesia, 5 February 1996).
\end{abstract}

In the book which is published from dissertation of Hakim in Jamia Millia Islamia, India, entitled "The Response of Muslim Youth Organization to Social-Political Change: A Case of HMI Role in Indonesia", the questions that will answered to explain the role and the contributions of HMI in the social political change in 1985's, post The Only Fundament Organization of Pancasila was conducted until the fall of Soeharto power in 21 May 1998. 
Masykur Hakim stated that HMI was founded in 1947 has the aims to defend the Unity of Republic Indonesia and to make prosperous of people, to maintain and to widen Islamic wisdom. The aims of HMI indicated of nationalism. Hakim stated that HMI declared Indonesianization. Hasanuddin also stated that HMI have made training to mobilize and to move in many cities for many other students' organizations in 1960-1970's. It means that HMI play significant role.

\section{Political Participation}

The term of political participation have defined by many political experts. Samuel P. Huntington and Joan M. Nelson in their book entitled Political Participation in the Developing Countries (1984) given the definition of political participation as personals' behavior, attitude and perception dealing with the relevance of personals' interest to influence the government decisions and action. The real political participation behavior is racial disturbance, the strike of workers etc. Considering to its aims are to influence government decision making, then Huntington and Nelson have written two important aspects. Firstly, political knowledge, political interest, feeling dealing with competition, and political effectiveness and relevance. Secondly, political participation of professional which has a job in politics or in governmental level. Thirdly, focused on public official because having authority to making decision in society.

According to Huntington and Nelson stated that, political participation in developing countries is how to change public official decisions, to change or maintain political organization system which becomes its rule player. The research of Huntington and Nelson has found two political participation categories are; mobilized participation and autonomous participation. The first model of participation based on the fact that many people give their vote, making demonstration, or another action seems not act by personal willing to influence governmental decisions. There is a unique thing in this research result that percentage of voters who use their vote right are high in Turkey. Turkey voters are traditional ones. In fact that most of voters in Turkey are farmers who are mobilized by land lord to use their vote right. Whereas, autonomous participation was defined as participation activity based on volunteering, without pressure from other side. Autonomous participation is truly based on the effort to influence the government decision. Although both of autonomous and mobilized participation are one spectrum but not absolutely. In democratic country tends to participate autonomous. 
In another society, according to Huntington and Nelson stated that participation is based on groups' belief. Most of participation involve collaboration and benefit for collectiveness, there are some common fundaments: (a) Class, personal with social status, similar wage and job; (b) Group, personal from racial, religion, language and ethnic; (c) Environment, personals who live close each other geographical location; (d) Party, personal who try to come to formal organization for controlling both in executive and legislative fields; and (e) Group, personal who are united by constant interaction which is realized in patronclient grouping form. By comparing with United State of America, the citizens' political participation there reflected on liberal development model. Huntington and Nelson stated that high autonomous participation can implemented by raising economical wealth as a whole, distribution of wealth as a fair, improving political stability, and setting up the fundament for broader participation with democratic governmental system.

Furthermore, Huntington and Nelson stated that the attitude of political elites toward political participation in every society is the most determined influence of political participation character in that society. Mobilized participation only happen if political elites making effort to involve mass of people into political activity. According to Huntington and Nelson, they stated that autonomous participation can be happen with not to higher sacrifice, if political elites do not oppress people. In traditional society, political participation less appreciate both elite and common people, because they still consider for respectful attitude and hierarchy formation.

On the contrary, Huntington and Nelson also found the basic difference with participation pattern in democratic political system. Participation in election is influenced by intensity and character than competition of voters and parties in society. For example, it has change drastically decline on social power that causes competition among parties after 1896 in USA. Because of both south and north tends to become single party power. In multiparty, every party tends to mobilize their supporters than making competition with other party by limitation intensity of political party competition.

In developing countries cases, broadening political participation are very rare. This is the main goal of political elite in developing countries. Broadening political participation is influenced by initiatives of political leaders who want to defend its power. People who hold the political power can be influence political participation; they prefer to strengthen their power and to strengthen political stability by limitation of broadening political participation. The effort to develop economic wealthy, equal distribution and stability in politic can be create requirement to broaden political participation. 
Huntington stated that people who become member of organization and take a part in organization actively, they have big possibility to take a part in politic. In fact, the involvement in organization maybe more important than social-economical status in political participation. The argumentation of this two American political scholars are supported by Almond-Verba data dealing with USA, England, Germany, Italy and Mexico. The data showed that social-economical status can be explained about 10 percent from differences in political participation; meanwhile the involvement can be explained about 25 percent in organization. Another study also has the same conclusion. One of function of economical development is the increasing of personal participation in group. In many countries, there is preference in educated community that better salary and occupation tends to involve in organization higher. The involvement of people who less status in organization is the impact of consciousness in unique group, class, communal group or environment. Meanwhile, individual intensity can identified as increasing of individual involvement in group. The possibility that individual will involve in organization and take a part in politic.

Elite group who control to government has more ability to broaden participation than elite group who not doing controlling function. To mobilized new group into politic is effective way. Huntington and Nelson considered that the effort to shift dominated power and to take over governmental controlling is one of effective way to broken the status quo. Meanwhile, ruling elite still try to limit their political participation. It is rare for the ruling power to broaden participation except, Firstly, if elite have no fundament for power or establish constituent, it is easy to overthrew by military, so that power must engage new power to keep their power; Secondly, ruling elite who dominated maybe will be forced to take action to mobilized other group into politic to support that ruling elite. Sometimes they found the reality that political elite participation is influenced by ideological background, especially their commitment to eliminate social class.

Dealing with this political participation, Huntington and Nelson written the fact that individual in a developing society has found that there is normal possibility order. That are, non-political individual action, individual political action, non-political collective action, and collective political action. The choice has done by elite, group, and individual between political participation and another ways to achieve the goal can be change. The changes of goal is depends on certain target. The temporary secular developing process is more extensive participation and more variety. 


\section{THE SUBJECT OF RESEARCH}

In relation to the process and role of HMI cadre-forming in occupying power structure in Indonesia, the subjects are going to discuss in this paper are on the cadre-forming system of HMI. Cadre-forming process in 1960's and 1970's had produced high quality alumni occupying various positions in both social and political and power structure in the decade 1990's.

Though cadre-forming process in HMI is relatively short on about five to seven years, but the cadres produced have a high quality and are pluralistic oriented in term of thought. Creating these high and pluralistic oriented cadres is not an easy job to carry out for they have been grown and educated in primordial environment, Himpunan Mahasiswa Islam (HMI).

HMI cadre-forming that emphasizes on the discourse and political thought supported by social and political condition influences political participation of HMI cadres in the power structure of the state. It is clearly that the case of HMI is engaged in political discourse and interest on politics, competition etc will influence political participation of politicians to engage in the power structure.

\section{THE HISTORY OF FOUNDATION AND STRUGGLE OF HMI}

The history of HMI was founded on 5 February 1947 in Yogyakarta. At that time, the condition of Indonesian political was still marked by the struggle for liberation in revolution period against to Dutch aggression. The idea to found HMI was inspired by idea was formulated by Jong Islamieten Bond (JIB) with its Islamic Studie Club to utter religiousintellectual and intellectual-religious. At that time, according to Victor Tanja, there was emptiness role of Islamic Youth intellectual because of JIB have been not exist again. There are several important figures in JIB such as Samsurizal and Natsir were not young anymore and became members of Masyumi political party. Lafran Pane with his friends, Kartono, Dahlan Husein, and Misroh Hilal, were students Sekolah Tinggi Islam (STI) (School of Islamic Studies), now become Universitas Islam Indonesia (UII) (Indonesian Islamic University) in Yogyakarta. They discussed to found HMI in their classroom. Tanja stated that the decision to found HMI because of the urgent needs for Youth Moslem Intellectual to take part in the struggle for national freedom. As an independence organization, HMI has expectation to be able to more its integrity toward duty of guarding in the interest of the state.

For Indonesian Moslem Community, the presence of HMI is very relevance to improve the quality of socio-educational and political in organizations. According to Tanja, 
the reason efforts of this new circle society's, is for completeness Islamis society toward modern teaching method. Moreover, pesantren (Indonesian Islamic boarding school) have played its role in spreading of Islamic literature and liberation religion thought. Dutch language was also used as introduction of teaching in pesantren. Beside HMI, Muhammadiyah movement is viewed as resurrection of Islamic spirit toward new age in Indonesia. Victor Tanja was viewed that the change of Muhammadiyah vision from socioeducation organization, which was tied strong with religion, to political struggle. In West Sumatra, Muhammadiyah tends to political interest was strong in past time. Afterwards, Muhammadiyah develop its neutral role in politic, give the political decision for members personally. Tanja stated that, although not focused on political directly, but Muhammadiyah develop political consciousness toward it members.

Meanwhile, Hasanuddin stated that history of HMI have been written by many writers earlier both alumni and not alumni of HMI. Agussalim Sitompul written, "Sejarah HMI dan Pemikiran HMI dan Relevansinya dengan Sejarah Perjuangan Bangsa" (History and Thought of HMI and its Relevance with the History of Indonesian Nation Struggle). Sulastomo in 1989 written “Hari-Hari Panjang: 1963-1966” (Long Days: 1963-1966) was told his witness in process of shift power from Old Order Period to New Order Period and the position of HMI at that time. Victor Tanja also has written dealing with HMI and its position in the middle of new movement in Indonesian Moslem.

In 1975, HMI conducted seminar to reformulate the motivation and background toward the foundation of HMI. The foundation of HMI was based on to develop Islam in Indonesia by preparing cadres who have high perception and commitment for Islam. Beside that, the foundation of HMI based on the wish to increase the Islamic quality of students' in performing the Indonesian nation history duty. Considering that sovereignty of country is important. From the historian aspect, Hasanuddin stated that the system of power for HMI is system of power which can support the development of Islam in Indonesia and this mainstream which is taken up by HMI in making interaction with social and political system. There were two important moments for HMI; first, was the physically struggle to face Dutch Military Action I, and second was the struggle to face the communist rebellion. The involvement of HMI in physical revolution to defend the freedom that made impressed the Indonesian leader. General Soedirman, the leader of Indonesian physical struggle for defending the freedom, said that the abbreviation of HMI is Harapan Masyarakat Indonesia (The Hope of Indonesian People). He supposed that HMI is not become separate from Islamic 
community. General Soedirman stated that when giving the speech in first anniversary of HMI in Yogyakarta (1948).

In 1950's, headquarter of HMI move from Yogyakarta to Jakarta. Since that time, HMI be able to formulate its position in the middle of Indonesian nation, HMI has functioned as Islamic Youth Organization, which have responsibility as agent of change toward nation and state. As the university students' organization, HMI have responsibility in university students' milieu, especially in college, and also as the supporter to the basic of Islam, responsible to how Islamic values can be operated in the society and state life. In the time of parliamentary democracy, HMI give the freedom to its members to choose one Islamic party. Although that decision above destroy the agreement among Islamic organization in 1949. In the subsequent developments, Hasanuddin see that HMI still consistent, for example, when HMI made the demeanor for all of Islamic fraction members in Konstituante (Constituent Assembly) by sent the letter, which was noted:

"To all of members in Konstituante as the owner of Indonesian Islamic ummah mandate's, we wish that you still struggle for that mandate and always maintain solidarity action among Islamic fraction as only one of the best weapon."

In 1961, when Soekarno announced NASAKOM (Nasionalis, Sosialis, Agama dan Komunis / Nationalist, Socialist, Religion and Communist), HMI made the moderate demeanor. This moderation demeanor was not like other big political organizations' attitude. HMI showed itself as accommodating organization and even embrace with another organization which has accommodating tradition, which was NU (Nahdlatul Ulama / Revival of Islamic Scholars). HMI also has dropped sanction to its members which made demonstration dealing with the power of NU in IAIN (Institut Agama Islam Negeri / State Institute of Islamic Studies) Yogyakarta. According to Hasanuddin, this step to save HMI from influence of PKI (Partai Komunis Indonesia / Indonesian Communist Party) in regime Soekarno. HMI got many protections from Islamic organization which was being able to cooperate with Soekarno, which was NU. The unwillingness of HMI was in confrontation with Soekarno directly because he still has very strong power. The big revolution leader, Soekarno, face big wave which willing to shift the power. But, actually the many members of HMI who involve to crash down the regime of Soekarno which was known as exponent ' 66 .

The policy of New Order Period, to spay Islamic political power systematically by making coalition with ABRI (Angkatan Bersenjata Republik Indonesia / The Army of Republic Indonesia), bureaucrat, and Golkar (Golongan Karya / The Group of Functionaries). For youth field, government to form KNPI (Komite Nasional Pemuda Indonesia / National 
Committee of Indonesian Youth) as an umbrella for all youth organization. Although HMI take part to be at the forefront of counter power, this was Cipayung Group. HMI also support Malari Movement in 15 January 1974. However, according to Hasanuddin, HMI did not react when government implemented NKK/BKK in 1978. Hasanuddin consider HMI as ambivalent demeanor. In one side, members of HMI as demonstration person, but in other side HMI, as organization, did not have courage to make pressure for government. The writer noted this as uniquely of HMI in its effort to safe itself.

\section{THE DEVELOPMENT OF HMI POLITICAL THOUGHT}

HMI was known as a cadre forming organization that greatly emphasized on a political orientation especially as a main source of political recruitment of state institutions like the People Representatives and civil servants, but HMI has various kinds of discourses, thoughts and ideas developed through cadre forming activities. Many discourses that HMI cadres had learned especially in the decades of 1960 and 1970's had developed fast into political thoughts, which is beneficial for the actualization of HMI cadres in occupying power structures in Indonesia.

\section{The Development of HMI Thoughts}

In the process of HMI, the study on Islam is put on priority. The basic reason of HMI founding, as known, was resulted in the Muslim restlessness on seeing the discontinuity of Muslim reform in Indonesia. This was proved in the time when a Islamic Youth Movement called Jong Islaminten Bond (JIB), in the time of Dutch and Japan colonization, only existed for one generation (1924-1945).

Syafi'i Ma'arif (former chairperson of Muhammadiyah) stated that, Jong Islaminten Bond, founded in 1925 by a genius Muslim intellectual KH Agus Salim. It had delivered some outstanding political cadres like Muhammad Roem (one of the founding fathers of Republic Indonesia), Muhammad Natsir (an intellectual and political figure becoming the symbol of nation morality). Syafi'i Ma'arif ultimately concluded that Jong Islaminten Bond was an intellectual and visionary generation and also the wisest generation in political field (Syafi'i Ma'arif, 1997). In the time of Jong Islaminten Bon generation, they were facing the ethical political system applied by the colonials, but this enabled them to have a high 
nationalist consciousness. In addition, the frictions among Islam, Nationalists and communists, at that time, had not risen yet. But HMI that was founded following Indonesian Independence was faced with internal conflicts among Indonesians. In the domain of Indonesian political superstructure, the enforcement of ideology and state constitution was the main reason for the existing conflicts. As Bactiar Effendy noted that the difference was presented in the form of polarization based on two ideological groups -- Nationalist and Religious groups. The first group emphasized on that Indonesia should not be based on the nationalist principle. This group was under coordination of Soekarno, Muhammad Yamin, Supomo and Muhammad Hatta. Moreover, this group proposed Pancasila to be used as the Indonesian principle in the reason that it would be widely accepted by all Indonesian existing groups. While the second group emphasized on the idea that Indonesia should be based on the religious principle. This group, led by Natsir, Wahid Hasyim, Ki Bagus, and Sukiman, proposed Islam as the Indonesian principle. They based on their ideas for some reasons. First, Islam is the religion, which provides guidelines for all aspects of life. Second, Islam is the religion of the majority of people in Indonesia. In June, 1945s, the solution had been found by adopting Jakarta Charter, a charter obliging Muslims to carry out Islamic teachings, which accommodated all interests of Islamic groups. But a day after Indonesian Independence, the Jakarta charter was cancelled and it was represented by the word "Believe in God" included in the first point of Pancasila. This historical fact inevitably has caused endless conflicts among the next generation for both nationalist and religious oriented groups failed to create a negotiated consensus on the political life.

HMI, in the ideological context, represented Muslims, especially modernist Muslims, and this emerged an accusation over HMI, in the guided democracy under Soekarno, that it was contra-revolution. This issue was also manipulated by Indonesian Communist Party to dismiss HMI from its existence for the party found that HMI and Islam was on the similar ideology and meant similar contender as well. The development of HMI thoughts on Islamic affairs found widely public sphere to contextually re-develop Islamic discourse when the New Order Regime was in power following the failed rebellion of the Indonesian Communist Party. In this time, it seemed that HMI found a momentum to express the hidden thoughts on the Islamic affairs. The roles of HMI in the beginning of the New Order Regime as an ideological response toward modernization process. In this very beginning process, the New Order Regime faced a great responsibility to carry out economical and political recovery under the economic crisis and a high inflation that were inherited by Old Older Regime in term of global strategy to build a new order. The Regime, in this early process, emphasized on 
the economical development and political stability as its first priority. It is argued that the regime proposed the concept of modernization for social and political life in implementing its developmental policy. The clash of different points of view on the modernization concept emerged in the time when all political entities, including HMI, agreed that modernization should be the means to solve all problems Indonesian faced.

The reason HMI accepted the developmental approach carried out by the New Order Regime was in relation to the re-interpretation on Islamic human values through a social and transformative school in the effort on creating harmonic and integral relation between Islam and the state concerning on some main points. First, the developmental process for egalitarian and participatory society. On the basis of complexity in the national affairs, an accommodative strategy or approach was, therefore, significantly in need for accommodating Muslims aspiration. Second, under New Order Regime, it was predicted that the state was getting stronger. Based on the point of view, Muslims, according to Bactiar Effendy (1990), needed to be directed toward understanding the wide meaning of politic covering programs, strategies and the area of struggle. HMI was also interested in formulating substantial and significant relations among the state, Islamic politics and other existing social and political institutions, which had similar visions. Moreover, HMI was interested in re-formulating the inclusive end of Islamic politics.

Islamic reform movements in Indonesia, in fact, was influenced profoundly by other movements in the Islamic countries through long term trading contacts and thought dynamics with, for example, Middle East countries. Fazlur Rahman, an outstanding Muslim scholar who currently has become a source of inspiration for HMI activists, introduced four models of development. First, Pre-modern revivalism movement or early revivalism, this movement was a reaction over the moral decadence of Muslims saturated by the rigidity of the reforming thoughts. In addition, this movement was directed to create fundamental transformation to overcome social and moral decadences over Muslims. Second, classical modernism movement, this movement was carried out through reforming educational institutions. The consequence of this model, especially in many Islamic and ex-colonized countries, was the adoption of the Western paradigm to measure the development achieved. Moreover, the Koran and Hadith were, consistently, used to justify western thoughts. Third, post-modern revivalism, in this phases the western thoughts, especially on politic, social and economic, provided equal meanings with the Islamic terms. In other words, these social and political movements were the basic accentuation of this well and modernly organized movements (Awad Bahasoan, 1984:110-112). 
This movement appeared in the modern phases, which was long experienced by Islamic countries through enlightenment process from XVI to XX century. While Indonesian reforming process was marked by the awakening of Islamic nationalism in the world in attempt of confronting western colonials and becoming prosperous and advanced Muslim society (Awad Bahasoan, 1984:110-112). Based political thoughts of Islam, Dien Syamsuddin (2001) argues that the relation between the ruling Islam and the ruled Islam had become an important issue in appearing the new theories concerning on both the relation between the two sides and the ideal society that would appear from the relation. The political thoughts of Islam actually express the long and sustainable intellectual process concerning on the nature of government roles as inseparable means to solve the religious and worldly affairs. As it is common in the intellectual tradition, political thoughts of Islam also present two points of view on the relation between the ruling Islam and the ruled Islam.

In this context, there is profound contradiction among political ulama toward the power, especially in the pre-modern era, which was influenced by geographic, social, political and cultural factors, thus in common the history of Muslim civilization put the ruling sides (Khalifah, Amir and sultan) in the superior position with absolute or divine power and sovereignty. It is mostly reflected for example in the title of sultan with Allah fi al-ardh (the representative of Allah in the earth) or zil Allah fil ardh (the shadow of Allah in the earth). The weak position of religious ulama in social sectors has motivated political ulama to legitimate the ruling party with religious reasons.

\section{HMI and Political Thoughts}

To explore and study the political thoughts of HMI was not an easy job, though when we mention the word "HMI", people will automatically related it with political field. For the image of HMI was rooted from strong political orientation. According to Nurcholish Madjid that in attempt to enforce Islamic and political mission of HMI, the thoughts on HMI politics develop in accordance with the growth of HMI thoughts. In every stage of process, HMI is urged to actualize itself as part of the whole Indonesian Muslims. Nurcholish Madjid argued that the conscience as part of Indonesian Muslims would create pluralist and independent behavior in the thoughts and culture of HMI.

The pattern of HMI participation is based on the ideological conscience of HMI as a political cadre with certain understanding on reality and ideology toward nationality affairs; 
and HMI hope on the ends and target, which need to be achieved by Indonesia as a plural nation. In addition, the hope and nationality vision are also adapted with political ideals of HMI since it was first founded, that is intellectual participation and participation to defend this state physically. The model of HMI participation in national and political life is active, this participation is reflected in the attitude and the roles of HMI in criticizing and confronting the process of national development (Nurcholish Madjid, 1999:16-17). According to Nurcholish Madjid, this participation has to be based on an independent participation both to internal and external Muslims like in relation to the political groups in national and political life. But HMI has to see the criticized developmental problems objectively whether it has been appropriate with developmental agenda that are needed by the people.

As an independent organization, HMI often has to confront with other Muslim resistance especially Mashumi. Greg Barton found that there is an implicit conflict between HMI and Mashumi (an Islamic political party) though it seems that their platforms are almost same. Barton argues that there is fundamental difference between HMI and other organizations especially political ones for HMI is an independent and established organization though in the past Indonesian Communist Party (PKI) had accused HMI as an inseparable part of Mashumi. To show its independence, HMI rejects to join in any existing political parties for HMI was critical to any existing political parties including Mashumi. In term of political development, in the Renville conference between Indonesia and Dutch, HMI was clash of ideas with Mashumi in which HMI totally supported to the conference. In addition, HMI supported secular ideology (Pancasila) for Indonesia while Mashumi supported Islamic constitution that had become ideals of the people at that time and the relation between HMI and Mashumi was at the worst time when HMI decided to support four Islamic political parties (Mashumi, Nahdatul Ulama' (NU), Partai Syarikat Islam Indonesia (PSII), and Perti (Barton, 1999:58-61).

In the guided democracy era (1950-1963), the political sphere especially in the internal Muslims was experiencing conflicts and was in fragile. In addition, between Islamic group and communist and nationalist group was in clash of interests and thoughts. Communist and nationalist groups accused HMI as reformer group, contra revolution and anti Pancasila. Nevertheless, this accusation strengthened the internal solidarity of HMI that it was able to formulate some useful thoughts for Islamic communities and for national affairs.

As organization with developmental oriented, HMI continually tried to achieve its interests by producing modern discourses on nationality affairs. There were at least five fundamental aspects that had become important discourse for HMI at that time - politics, 
education, religion, economy, and culture. Before, HMI generally had futuristic thoughts on nationality affairs. Endang Saifuddin Anshari outlined that there three important dimensions to note in discussing commitment of nationality (HMI called it Indonesian values); Indonesia as a country, Indonesia as a nation and Indonesia as state. In term of Indonesian as a country, Endang explained the strategic position of Indonesia that is surrounded by two oceans Pacific and Hindia - and tens of islands, big and small, located in the equator lines, therefore Indonesia is strategic both economically, politically, socially and culturally. In term of Indonesian as nation, Indonesia is pluralism in form of races, religions, traditions, local languages and many more, therefore HMI as an Islamic organization pays much attention to the pluralism. In this context, HMI should play an important role to implement national integration (Ade Komaruddin and M. Fauzie, 1990).

In relation to the political thoughts of HMI, the relation between religion and political aspects will be discussed in details. From the religious perspective, the interpretation of the HMI principle shows that the truth of Islam is perfect in which it will enable human beings to be happy both in the world and hereafter. In additon, HMI will participate to implement Muslim's sacred missions to invite human being into truth. Agus Salim Sitompul and Greg Barton agree that since first time HMI supported Pancasila as an ideology. In this context, Muslims are required to keep struggle for the future and HMI, as nation cadre and future generation, is required to formulate humanity agenda because Islamic university students are considered as Ummah cadres to continue Muslim ideals. Ismail Hasan (HMI chairperson in 1958) argued that NDP had to be HMI zeal to achieve its final targets. Further he insisted that HMI should have moral belief, high intellectuality and creativity.

HMI is a moderate organization, which can adapt with any existing political reality. In this context, HMI tried to overcome marginalization process by government and to eliminate political decay in Muslim community. Even, HMI tried to solve any problems concerning on the nationality basis. Nevertheless, the state tried to hinder and limit the growth of political ideology of Islam. In the weakening of Islamic politics, HMI continually conducted wide cadre process to create Muslim cadre that could be recruited into the political structure in the future. In the guided democracy era, when Soekarno was to establish Kabinet Gotong Royong that would include Indonesian Communist Party (PKI), HMI demanded that Piagam Jakarta be applied in which Islam was the state was based on Islamic principles. In the fifth congress of HMI in Medan (1957), it decided that Islamic state had to be established in Indonesia. In fact, this demand was in relation with constitution committee (Konstituante) that was discussing in attempt to replace the temporary constitution of 1950. 
Agussalim Sitompul stated there were two important factors that formed the background of the political thoughts of HMI. First, that our independence from colonial domination was an absolute achievement for colonial domination brought great disadvantages for our nation and our people. HMI suggested that if Indonesia was still dominated by colonials, people sovereignty should be enforced to achieve people independence. In 1950s, it seemed that Dutch's influence was still strong for the domination was not merely physically but also spiritually (for example, the arrival of Jending mission to Indonesia). According to HMI, Indonesia should be equal with other nations in the world. Second, the political thoughts of HMI were explained in the First Anniversary of HMI in Bangsal kepatihan Yogyakarta in February 6, 1948. Ahmad Tirtosudiro, the vice-chairperson of HMI, in his speech stated:

"Based on the sociological perspective, the form of Indonesian state should be appropriate with characters and condition of our society, therefore the western dogma and theories should be observed before they were adopted. For it would change the social structure of Indonesian people"

In the end of his speech, he stated that Indonesian students had to pay attention to their social functions and had to engage in the social reality. They had to keep in mind the statement that says "a politician that does not know sociology like a ship man that does not know the course of the wave and the line of sea reef mountains, and he would be collapse in the middle of the ocean".

When HMI was faced with Indonesian Communist Party (PKI), HMI under Soelastomo tried to be accommodative with political manifesto of Soekarno known as Nasakom. Dahlan Ranuwihardjo who knew directly all PKI's efforts to dismiss HMI thought to meet Soekarno to explain HMI position and asked not to dismiss HMI and suggested Soekarno to bring HMI into his revolutionary politics. To implement his thought to meet Soekarno, he applied hidden strategy. Most of his seniors did not agree with his steps and suggested that HMI, like Mashumi and GPII, to reject Pancasila and other political manifestations as an organization ideology. Dahlan finally could meet Soekarno and discussed in details on the HMI position. In the meeting, Dahlan applied Breed front strategy and produced Gunung Puyuh Agreement. This strategy stated that if Soekarno dismissed HMI, it could be predicted that HMI would engage in the separatist movements like DII/TII.

According to Dahlan Ranuwihardjo, his meeting with Soekarno was a form of political deal and a way to clean HMI from ex-GPII members. In addition, this meeting was intended to make HMI a supporting force for our state principles - Pancasila and Nasakom. Soekarno also would free HMI to conduct cadre-forming process and political education for its 
members generally called Kursus Kader Revolusi and he issued president's decree that would control HMI. This lobby was considered as an indication that HMI would win the competition against its political contenders, and it was proved that HMI was the winner in the competition. In addition, HMI was also able to face any attacks to dismiss it. This was not only caused by political deals between Soekarno and Dahlan Ranuwihardjo but because all elements within HMI from Local to central organization plus LDMI and LAPMI were consistent to defend the existence of HMI.

Since 1970s and 1980s, we have seen new intellectual processes that have been pioneered by HMI. According to Bachtiar Effendy, there were at least three fields of thoughts that played a significant role in changing old Islamic activism and intellectualism; reformation of Islamic thoughts, political and bureaucratic reformation and social transformation. The three sectors carried out reformation movement collectively. For example, reformation of Islamic thoughts emphasized on the dynamic of the changing world. Bureaucratic and political reformation emphasized on the Muslim involvement in the bureaucratic and political life of the state and cultural groups (social transformation) conducted people empowerment in the grass roots. All this were intended to empower Muslim community in the economic and political fields. Therefore, in the future they would be able to support the construction Muslim community that focused on the values of justice, equality, discussion, and Pancasila (Bahtiar Effendy, 2001:91-93).

It seemed that transformation of HMI political thoughts was well responded by New Order Regime, therefore since 1980s New Order Regime had accommodated significantly the political aspiration of the Muslims. R William Liddle (Kompas, 1990) stated that Nurcholish Madjid's statement Islam Yes, Islamic Party No is an appropriate political slogan to express the roles of Muslims in democratic, stabile and effective Indonesian government. Indonesian Muslims in the New Order Regime did not struggle through political parties as in the Old Regime, but they struggled through social organizations (HMI) that to achieve their interests and visions in the political arena including executive and legislative member.

\section{CONCLUSION}

HMI is not political organization, but it puts concern on the political issues that make HMI accused as pressure group. HMI though is only intense in the issues of intellectuality, Indonesianism and Islamism but sometimes it also engages in political roles that can 
ultimately create new problems for it. This paper described how the political participation of HMI. The former adopted authoritarian and the later adopts a democratic political system. This research is, finally, explained the influences of HMI domination on the power. This is conducted in relation to the decline of the cadre quality and strategic roles of HMI in reformation movement. In this context, HMI should function as critic and power controller. This study is not, of course, intended at merely producing descriptive and phenomenological knowledge on HMI as sources of political recruitment in the power structure but also intended to provide values added toward the development of political science, especially the theory of political participation.

\section{REFERENCE}

Ade Komaruddin and M. Fauzie, (Eds). (1990). HMI Menjawab Tantangan Zaman, Agussalim Sitompul. 1995. Historiografi HMI (1947-1993). Jakarta: Intermassa. Ahmad Doli Kurnia. (2002). Meluruskan Jalan Ke Khittah HMI. Yogyakarta: Belukar. Akbar Tanjung. (1997). HMI dan KAHMI Menyongsong Perubahan, Menghadapi Pergantian Zaman. Jakarta:KAHMI.

Awad Bahasoan. (1984). Gerakan Pembaharuan Islam: Interpretasi dan Kritik. Jakarta:LP3ES.

Bachtiar Effendy. (1990). Islam and the State: The Contribution of Islamic Parties to the Decline of Democracy in the 1950. Unpublished articles.

Bahtiar Effendy. (2001). Teologi Baru Politik Islam (Pertautan Agama, Negara dan Demokrasi). Yogyakarta:Galang Press.

Barton, G. (1990). Gagasan Islam Liberal Indonesia: Pemikiran Neomodernisme Nurcholish Madjid, Djohan Effendi, Ahmad Wahib dan Abdurahman Wahid. Jakarta: ParamadinaPustaka Antara, Jakarta.

Dien Syamsuddin. (2001)., Antara Yang Menguasai dan Yang Dikuasai (A Scientific Speech on Political Thoughts of Islam at his appointment as Proffessor lecturer in State Islamic University (UIN) Jakarta, Jurnal Katalis, Vol 1/2/2001.

Hasanuddin M. Saleh. (1996). HMI dan Rekayasa Asas Tunggal Pancasila. Yogyakarta: KS Lingkaran \& Pustaka Pelajar.

Huntington, S. P. (1984). Partisipasi Politik Di Negara Berkembang. (Political Participation in Developing Area). (Hasan Basri, translator) Jakarta: Sangkalar Pulsar.

Kartini Kartono. (1989). Pendidikan Politik (Sebagai Bagian Dari Pendidikan Orang Dewasa). Bandung: Mandar Maju.

Kompas, February 7, 1990.

Masykur Hakim. (2001). Pergolakan Reformasi dan Strategis HMI. Jakarta: Al-Ghazaly.

Muhammad Kamal Hassan. (1987). Modernisasi Indonesia: Respon Cendekiawan Muslim. Jakarta: LSI.

Nurcholish Madjid. (1999). Wacana Kenegaraan HMI (Sebuah Pengantar) Mahasiswa dan Wacana Kenegaraan (Kumpulan Rekomendasi Kongress HMI 1971-1999).

Ramli H.M. Yusuf (ed). (1997). 50 Tahun Mengabdi Republik. Jakarta: LASPI.

Sidratahta Muchtar. (2002). Ketika HMI Menjadi Beban Bangsa. Media Indonesia.

Syafi'i Ma'arif. (1997). Tidak Ada Negara Islam; Muhammad Roem and Nurcholish Madjid, "Dialog Dua Generasi. Jakarta:Jembatan.

Syaifullah S.A. (1994). Konsep Nasionalisme HMI Sebagaimana Tersermin dalam Pidato 
Dies Natalis dan Penerapannya Dalam Gerakan Angkatan '66. Disertasi. Jakarta: PPS IAIN Syarif Hidayatullah.

Victor Tanja. (1982). Himpunan Mahasiswa Islam (HMI), Sejarah dan Kedudukannya di Tengah Gerakan-Gerakan Muslim Pembaharu di Indonesia. Jakarta: Sinar Harapan. 